\title{
In Vitro Induction of IgG1 and IgG2 Secretion by B Cells of Children Who Developed Invasive Haemophilus Disease despite Vaccination
}

\author{
ANITA CHACKO AND DAN M. GRANOFF \\ Edward Mallinckrodt Department of Pediatrics, Washington University School of Medicine and the Division of \\ Infectious Diseases, St. Louis Children's Hospital, St. Louis, Missouri 63110
}

\begin{abstract}
Lymphocytes from seven patients who developed Haemophilus influenzae type b (Hib) disease after being vaccinated with Hib polysaccharide vaccine and from one patient who developed disease after conjugate vaccination were investigated for the ability to secrete IgG1 and IgG2, in vitro, in response to a combination of pokeweed and Staphylococcus aureus Cowan I mitogens. The eight patients were selected because they had low anticapsular antibody responses to Hib disease. Only one of the eight children had a history of previous severe, recurrent infections. This child (in whom a polysaccharide vaccine failed) had a deficiency of the second component of complement and also had a subnormal serum concentration of IgG4. Only one of the eight children, an otherwise healthy 54mo-old with normal serum Ig concentrations, had subnormal mitogen-induced B-cell secretion of IgG1 and/or IgG2. When this child's lymphocytes were separated into $\mathrm{T}$ - and B-cell fractions and cocultivated with the respective fractions of the father's lymphocytes, the child appeared to have an intrinsic B-cell defect and normal $T$ cells. There were no significant differences $(p>0.3)$ in the respective geometric means of the in vitro secretion of IgG1 or IgG2 of the $B$ cells from the children with polysaccharide vaccine failure and those of 14 healthy controls of similar ages as the patients (IgG1, 1524 versus $3497 \mathrm{ng} / \mathrm{mL}$ per $10^{5} \mathrm{lym}$ phocytes; IgG2, 79 versus $89 \mathrm{ng} / \mathrm{mL}$ per $10^{5}$ lymphocytes). Thus, despite the presence of impaired serum anticapsular antibody responses to $\mathrm{Hib}$ disease, most children who develop Hib disease after Hib polysaccharide vaccination have normal in vitro B-cell secretion of $\operatorname{IgG1}$ and $\operatorname{IgG} 2$ in response to mitogens. (Pediatr Res 30: 124-129, 1991)
\end{abstract}

\section{Abbreviations}

Hib, Haemophilus influenzae type b PS, polysaccharide

PBMC, peripheral blood mononuclear cell

SRBC, sheep red blood cell

PWM, pokeweed mitogen

$\mathrm{C} 2$, second component of complement

PRP, polyribysl ribitol phosphate

Received November 12, 1990; accepted March 13, 1991

Correspondence and reprint requests: Dan M. Granoff, M.D., Department of Pediatrics, Division of Infectious Diseases, St. Louis Children's Hospital, 400 South Kingshighway Blvd., St. Louis, MO 63110.

Supported by Grants AI 17962 and AI 21842 from the National Institute of Allergy and Infectious Diseases, and Grant RR-36 from the General Clinical Research Center Branch, NIH.
Hib PS vaccine was first licensed in the United States in 1985. It soon became apparent that this vaccine was incompletely protective in children $\geq 24$ mo of age, the principal age group targeted for immunization $(1-3)$. The reasons why vaccination failed to protect some children are unclear (1-4). Most of the children with vaccine failure were found not to have underlying conditions, such as sickle cell disease, previous splenectomy, or hypogammaglobulinemia, which predispose to an increased risk of Hib disease $(1,4)$. Although children with vaccine failure had normal antibody responses to protein antigens, such as tetanus toxoid (1), many were found to have impaired serum antibody responses to the Hib PS capsule, both after recovery from invasive Hib disease (1) and after reimmunization with Hib PS vaccine (5). These observations suggested a selective antibody deficiency to the Hib PS antigen in some of the children. However, the antibody unresponsiveness of the children could be overcome by vaccination with Hib PS conjugated to protein carriers $(5,6)$, and the antibody elicited expressed the same, recently described, dominant cross-reactive idiotype on antibody elicited by Hib vaccination of most healthy children and adults (7, unpublished data).

The underlying cellular immune defects involved in the impaired serum anticapsular antibody responses of patients who did not respond to Hib PS are unclear. PS-protein conjugate vaccines are thought to confer thymic-dependent properties to the PS component of the vaccine (8). Thus, the ability of the children with vaccine failure to respond to Hib PS-protein conjugate vaccines, but not to unconjugated $\mathrm{Hib} \mathrm{PS}$, favors the hypothesis that these children possess $\mathrm{B}$ cells that are able to expand and differentiate into Hib PS antibody secreting cells with the help of $T$ cells. But, for reasons that remain unexplained, their B cells do not respond normally to the thymicindependent form of the Hib PS antigen.

Measurement of in vitro Ig production by B cells stimulated with mitogens has been used to evaluate patients suspected of having a variety of immunodeficiencies, including common variable immunodeficiency (9-11) and IgG subclass deficiency (1214). In addition, children with recurrent bacterial infections associated with normal serum Ig concentrations but abnormal antibody responses to specific antigens have been reported to show in vitro abnormalities of $\mathrm{T}$ - and $\mathrm{B}$-cell function, including abnormal secretion of IgG subclasses in response to mitogen stimulation $(15,16)$. Little is known about the function of $T$ and $B$ cells in patients with $\mathrm{Hib}$ vaccine failure. The purpose of our present study was to determine whether B cells from such patients demonstrate abnormal in vitro secretion of $\operatorname{IgG} 1$ and $\operatorname{IgG} 2$ in response to mitogen stimulation.

\section{MATERIALS AND METHODS}

Subjects. The protocol was approved by the Human Studies Committee of Washington University School of Medicine. The 
principal patient group consisted of six children with a history of culture-proved invasive Hib disease, with the onset of the disease occurring 3 to $11 \mathrm{mo}$ after Hib PS vaccination. As described in the results, except for minor illnesses, these six children were otherwise healthy, and none of the six had a history of previous episodes of bacteremia. Data from two additional patients who developed Hib disease after vaccination are included in this report, but because one developed disease after conjugate vaccination and the other had recurrent invasive bacterial disease and a deficiency of $\mathrm{C} 2$, the data from the two were analyzed separately.

At the time of our study, the eight children ranged in age from 48 to 84 mo (median $=60 \mathrm{mo}$ ). All eight children resided in Missouri or Illinois and were selected based on their availability and the willingness of their parents to consent to these studies In addition, all eight children had $<1 \mu \mathrm{g} / \mathrm{mL}$ of anticapsular antibody in serum obtained 2 to 11 mo after the onset of Hib disease (median $=6 \mathrm{mo}$ ). The serum antibody responses of seven of the eight children to Hib conjugate vaccines have been described in previous reports $(5,6)$.

The control subjects for the B-cell studies consisted of 14 healthy children, ranging in age from 43 to 92 mo (median $=62$ mo). All of the control children resided in the St. Louis area and were the same ages as the patients with vaccine failure. As an additional control group, lymphocytes from a healthy parent of each patient and each control child were fractionated and cultured in vitro on the same day as those of the respective child. This group of adults was included to control for variability in cell separation and culture techniques that might result in poor Ig secretion by the child's lymphocytes. In addition, as described below, the parents' lymphocytes were used for the cocultivation experiments with the $\mathrm{B}$ and $\mathrm{T}$ cells from their children.

General Immunologic Evaluation. Serum concentrations of $\mathrm{IgG}, \operatorname{IgA}$, and $\operatorname{IgM}$ were measured by nephelometry (Beckman Instrument, Inc., Fullerton, CA). Serum concentrations of IgG1, IgG2, IgG3, and IgG4 were measured by particle concentration fluorescence immunoassay, as previously described (17). In five patients, enumeration of lymphocyte populations was performed by incubating peripheral blood mononuclear cells, separated by Ficoll-Hypaque density sedimentation, with FITC-conjugated $\mathrm{MAb}$ and examining the cells by fluorescent microscopy (Labophot; Nikon, Tokyo, Japan). The MAb used were anti-Leu 16, anti-Leu 5B, anti-Leu 3A, and anti-Leu 2A (Becton-Dickinson, Immunocytometry Systems, Mountain View, CA) to quantitate $\mathrm{B}$ cells, $\mathrm{T}$ cells, $\mathrm{CD} 4$ cells, and $\mathrm{CD} 8$ cells, respectively. In the remaining three patients, enumeration of lymphocyte populations was performed on heparinized blood, using the commercially available Coulter Immuno-Prep method (Coulter Diagnostics, Hialeah, FL). After lysis of the red cells, membrane stabilization, and fixation of the lymphocytes, the FITC-conjugated $\mathrm{MAb}$ described above were used to determine the respective lymphocyte surface markers by flow cytometry (Coulter-Epics Profile, Hialeah, FL). Cells from two patients were enumerated by both flow cytometry and the manual method described above, and there was good agreement between the respective results.

Measurement of In Vitro Secretion of $\operatorname{Ig} G 1$ and $\operatorname{Ig} G 2$ by Mitogen-Stimulated B Cells. Lymphocyte separation. PBMC were obtained from heparinized blood by Ficoll-Hypaque density sedimentation as described (18). Except where noted, each patient and control were studied on one occasion. Partial depletion of monocytes was achieved by adherence of the PBMC to plastic surfaces. Briefly, PBMC at $2 \times 10^{6}$ cells $/ \mathrm{mL}$ were incubated in $15 \mathrm{~mL}$ of RPMI 1640 (J.R. Scientific, Ballwin, MO) containing $10 \%$ FCS (Hyclone Laboratories, Logan, UT) in $75-\mathrm{cm}^{2}$ polystyrene flasks at $37^{\circ} \mathrm{C}$ for $30 \mathrm{~min}$. Nonadherent cells were incubated overnight with neuraminidase-treated SRBC. The next morning, the spontaneous rosettes formed by $\mathrm{T}$ lymphocytes with the SRBC were separated from the B-cell fractions by density sedimentation on Ficoll-Hypaque. The B-cell fraction was harvested from the interface between the Ficoll-Hypaque and the RPMI
1640 medium and washed once with Hanks' balanced salt solution (J.R. Scientific) and resuspended in RPMI 1640. The rosetted $\mathrm{T}$ cells were harvested from the pellets, washed with $1 \%$ $\mathrm{NH}_{4} \mathrm{Cl}$ buffer, $\mathrm{pH} 7.4$, to lyse the SRBC, and then centrifuged for $10 \mathrm{~min}$ at $350 \times \mathrm{g}$. The $\mathrm{T}$-cell fraction in the pellet was washed once with Hanks' balanced salt solution and then resuspended in RPMI 1640.

Enumeration of lymphocyte subpopulations. Total $\mathrm{T}$ cells, B cells, and monocytes were quantitated in the T- and B-cell fractions, using FITC-conjugated MAb anti-OK $\mathrm{T}_{3}$ (Ortho Diagnostic Systems, Raritan, NJ), anti-Leu 16, and anti-Leu $\mathrm{M}_{3}$ (Becton-Dickinson), respectively. A total of $2 \times 10^{6}$ cells were incubated with $20 \mu \mathrm{L}$ of each MAb for $30 \mathrm{~min}$ at $4^{\circ} \mathrm{C}$, followed by fixation with $1 \%$ paraformaldehyde and examination by fluorescent microscopy. The $\mathrm{T}$-cell fractions contained 80 to $90 \% \mathrm{~T}$ cells $(<2 \%$ monocytes, $<2 \%$ B cells $)$. The B-cell fractions contained 40 to $55 \%$ B cells, 10 to $25 \%$ monocytes, and $<2 \%$ T cells.

Culture conditions. Equal numbers of lymphocytes in the Tand B-cell fractions from patients were cocultivated together or with counterpart lymphocytes from a healthy parent in the presence or absence of mitogen in 96-well microtiter plates (Falcon Microtest III, Maryland Heights, MO). A total of $1 \times$ $10^{5}$ cells per well were cultured in triplicate in a final volume of $200 \mu \mathrm{L}$ of RPMI 1640 medium supplemented with L-glutamine $(2 \mathrm{mM})$, gentamicin $(50 \mu \mathrm{g} / \mathrm{mL})$, and $10 \%$ heat-inactivated FCS (Hyclone). Incubation was for $7 \mathrm{~d}$ in a humidified atmosphere at $37^{\circ} \mathrm{C}$ with $5 \% \mathrm{CO}_{2}$. Cultures were stimulated with a mixture of two mitogens: PWM (Sigma Chemicals, St. Louis, MO) at dilutions of 1:1000 and 1:3000 in RPMI 1640 and Staphylococcus aureus Cowan I (Enzyme Center, Inc., Malden, MA) at 0.02 and $0.005 \% \mathrm{vol} / \mathrm{vol}$, respectively. The specific dilutions of the combination of the two mitogens were selected based on the maximal $\mathrm{Ig}$ secretion response to a series of mitogen dilutions performed in earlier experiments. Supernatants from triplicate wells were pooled and stored at $-70^{\circ} \mathrm{C}$ until they were assayed.

IgG Subclass ELISA. Concentrations of $\operatorname{IgG} 1$ and $\operatorname{IgG} 2$ were measured in the supernatants, using a "capture" ELISA as previously described (19). MAb HG11 (20) was used for the detection of IgG1. HP6016, a MAb specific for the human isoallotype $\mathrm{G} 4 \mathrm{~m}(\mathrm{~b})$, present on all $\mathrm{IgG} 2$ molecules and on a subset of IgG4 molecules, was used to detect $\operatorname{IgG} 2(21,22)$. The latter antibody was selected instead of two other commonly used MAb, HP6014 or GOM1 (which are specific for IgG2), to avoid the $\lambda$-lightchain bias of HP6014 (17) and the low affinity of GOM1 (22). For our purposes, detection of the $\mathrm{G} 4 \mathrm{~m}(\mathrm{~b})$ isoallotype was found to be suitable for measurement of $\operatorname{IgG} 2$ secretion because the concentrations of $\mathrm{IgG} 4$ in the supernatants were so low that essentially all of the $\mathrm{G} 4 \mathrm{~m}(\mathrm{~b})$ detected was $\mathrm{IgG} 2$.

Briefly, Dynatech Immunolon 2 plates (Dynatech Laboratories, Inc., Chantilly, VA) were coated with $10 \mu \mathrm{g} / \mathrm{mL}$ of the respective $\mathrm{MAb}$ in $10 \mathrm{mM}$ Tris saline buffer, $\mathrm{pH} 8.5$, and incubated for $4 \mathrm{~h}$. Plates were washed with $20 \mathrm{mM}$ Tris saline buffer, $\mathrm{pH} 7.4$, containing $0.05 \%$ Tween 20 . Uncoated sites were blocked with $1 \%$ BSA diluted in the Tris saline wash buffer. Serial 4-fold dilutions of the culture supernatants were added, starting at 1:40 for the IgG1 assay and 1:4 for the IgG2 assay, and incubated overnight at $4^{\circ} \mathrm{C}$. After washing and blocking, bound IgG1 and IgG2 were detected, using an alkaline phosphatase-conjugated goat antihuman IgG, which had been adsorbed to remove reactivity with mouse Ig (Sigma Chemical Co., St. Louis, MO). In addition, we added normal mouse serum and normal goat serum $(2 \% \mathrm{vol} / \mathrm{vol})$ to the alkaline phosphatse conjugate of goat antihuman IgG to decrease nonspecific reactivity in the assay. $p$-Nitrophenyl phosphate disodium at $1 \mathrm{mg} / \mathrm{mL}$ in diethanolamine buffer, $\mathrm{pH} 9.8$, was used as the substrate. A human purified IgG1 myeloma protein was used as the standard in the IgG1 assay. Because of insufficient quantity of a purified IgG2 myeloma protein, dilutions of a secondary standard, consisting of a human serum pool designated HSP-3 (17), were used 
as the reference serum in the $\mathrm{IgG} 2$ assay. The lower limit of detection of $\operatorname{IgG} 1$ and $\mathrm{IgG} 2$ was $10 \mathrm{ng} / \mathrm{mL}$. Culture supernatants from each patient were assayed in parallel with those of controls of similar age. For quality control, two control pools of culture supernatants were tested in every assay. In eight assays, the mean $\mathrm{IgG} 1$ and IgG2 concentrations of pool 1 were 3350 and $171 \mu \mathrm{g} /$ $\mathrm{mL}$, and those for pool 2 were 20 and $15 \mu \mathrm{g} / \mathrm{mL}$. The mean variation of values for replicate samples tested on different days was $16 \%$ for the IgG1 assay and $10 \%$ for the $\operatorname{IgG} 2$ assay.

Statistical Analyses. The in vitro $\mathrm{IgG} 1$ and $\mathrm{IgG} 2$ secretion values were transformed logarithmically, and the mean logs of the values of the patients and controls were compared by the $t$ test. In addition, the median values of the logs were compared by the Robust analysis.

\section{RESULTS}

Clinical Characteristics of Patient Group. Table 1 summarizes the clinical characteristics of the patients with vaccine failure. All of the patients were Caucasian, and $50 \%$ were male. Two of the patients with PS vaccine failure had a history of mild asthma, and a third patient had a history of recurrent episodes of otitis media. Three children were healthy before and after recovering from invasive Hib disease. As noted in Materials and Methods, two additional patients with vaccine failure differed clinically from the six patients described above, and, therefore, the data from the two were analyzed separately. Patient 7 had a history of severe recurrent bacterial infections and was known to have a deficiency of $\mathrm{C} 2$. The recurrent infections in this child included sinusitis, otitis media, pneumonia, and two previous episodes of Streptococcus pneumoniae bacteremia. Patient 8 was an otherwise healthy child who developed invasive Hib disease 5 mo after being immunized with Hib PS-diphtheria toxoid (PRP-D) conjugate vaccine.

Immunologic Evaluation. Anticapsular antibody concentrations. The mean age at vaccination of the seven children with Hib PS vaccine failures was $28 \mathrm{mo}$, and the mean age at onset of invasive Hib disease was $35 \mathrm{mo}$. The one child with conjugate vaccine failure was 18 mo of age at vaccination and 23 mo of age at onset of disease. After recovery from Hib disease, all of the eight patients had $<1 \mu \mathrm{g} / \mathrm{mL}$ of anticapsular antibody in convalescent serum (Table 1). Of note, before onset of Hib disease, patient 7 had been vaccinated twice with Hib PS vaccine at 24 and 30 mo of age. His serum antibody concentrations before and after vaccination and revaccination were $0.07,0.08$, and $0.08 \mu \mathrm{g} / \mathrm{mL}$, respectively. At $38 \mathrm{mo}$ of age, he developed periorbital cellulitis and Hib bacteremia. Two mo after onset of the disease, his serum antibody level was $0.14 \mu \mathrm{g} / \mathrm{mL}$.

Response to reimmunization. The eight patients were reimmunized with Hib PS vaccine and/or Hib conjugate vaccine at a median interval of 6 mo after onset of Hib disease. Four children were given Hib PS vaccine, and only one responded with antibody $>1.0 \mu \mathrm{g} / \mathrm{mL}$ (patient $2,3.3 \mu \mathrm{g} / \mathrm{mL}$ of antibody). The three nonresponders (patients 4-6) had $0.40,0.07$, and 0.58 $\mu \mathrm{g} / \mathrm{mL}$ of antibody, respectively, after revaccination. These three patients and the four remaining patients who were not reimmunized with Hib PS vaccine were given one or two doses of $\mathrm{Hib}$ conjugate vaccine (PRP-meningococcal outer membrane complex conjugate vaccine, four patients; PRP-D conjugate vaccine, three patients). As previously reported $(5,6)$, all seven children showed 5-fold or greater increases in serum antibody concentration, including the three patients who did not respond to reimmunization with Hib PS vaccine.

Serum Ig concentrations and circulating $T$ and $B$ cells. The seven patients with Hib PS failure had normal serum concentrations of IgM, IgA, and IgG. In contrast, patient 8, the child with the PRP-D conjugate vaccine failure, had a low serum IgM concentration $(31 \mathrm{mg} / \mathrm{dL})$ and a borderline $\operatorname{IgA}$ concentration $(19 \mathrm{mg} / \mathrm{dL})$. Table 2 summarizes the serum IgG subclass concentrations. The IgG subclass concentrations were normal except for a borderline subnormal concentration of $\mathrm{IgG} 4$ in patient 1 and a subnormal concentration of $\operatorname{IgG} 4$ in patient 7 , the child with C2 deficiency. The percentage of circulating T3, T4, and $\mathrm{T} 8$ cells and the percentage of $\mathrm{B}$ cells were normal in all eight patients (Table 2).

In vitro secretion of $I g G 1$ and $I g G 2$. Table 2 shows the concentrations of $\operatorname{IgG} 1$ and $\operatorname{IgG} 2$ secreted by B cells stimulated, in vitro, with the combination of $S$. aureus Cowan I and PWM. Only one of the eight patients (patient 5) had subnormal in vitro secretion of IgG1 and IgG2. Of note, patient 1 , who had a borderline subnormal serum IgG4 concentration, and patient 8 , who had a subnormal serum concentration of IgM and a borderline concentration of IgA, had normal in vitro B-cell secretion of IgG1 and $\mathrm{IgG} 2$. Because of the small quantities of culture supernatant and because in vitro secretion of IgG4 is below the detection limit of our assay, in vitro secretion of IgM, IgA, or IgG4 was not measured.

Figure 1 shows the individual B-cell secretion of IgG1 and IgG2 for the six patients with "primary" Hib PS vaccine failure and the corresponding values for the 14 healthy control children and 20 healthy adults. The median B-cell secretion of IgG1 was similar in the control children and healthy parents (8085 versus $6150 \mathrm{ng} / \mathrm{mL}$ per $10^{5}$ lymphocytes, $\left.p<0.9\right)$. In this analysis, the data from the parents of the patients and the parents of the control children were combined because there was no significant difference in the values obtained for these two groups of adults. Examination of the individual $\lg \mathrm{G} 1$ secretion values of the patients with vaccine failure and control children also indicates that there is considerable overlap between the two groups. There was a trend for lower IgG1 secretion in the patients, but the difference was not statistically significant (geometric means of 1524 versus $3497 \mathrm{ng} / \mathrm{mL}$ per $10^{5}$ cells, $p=0.32$ by $t$ test; medians

Table 1. Clinical characteristics of patients with Hib vaccine failure

\begin{tabular}{|c|c|c|c|c|c|c|}
\hline $\begin{array}{l}\text { Patient } \\
\text { no.* }\end{array}$ & Sex & $\begin{array}{c}\text { Age at } \mathrm{Hib} \\
\text { vaccination } \\
\text { (mo) }\end{array}$ & $\begin{array}{l}\text { Age at } \\
\text { disease } \\
\text { (mo) }\end{array}$ & $\begin{array}{c}\text { Hib } \\
\text { disease }\end{array}$ & $\begin{array}{c}\text { Convalescent } \\
\text { anti-PRP } \\
\text { antibody } \dagger \\
(\mu \mathrm{g} / \mathrm{mL})\end{array}$ & $\begin{array}{c}\text { Clinical history before Hib } \\
\text { disease }\end{array}$ \\
\hline 1 & M & 24 & 34 & Meningitis & 0.15 & Healthy \\
\hline 2 & $\mathrm{~F}$ & 27 & 31 & Epiglottitis & 0.15 & Healthy \\
\hline 3 & M & 45 & 48 & Meningitis & 0.16 & Asthma \\
\hline 4 & $\mathrm{~F}$ & 25 & 36 & Epiglottitis & 0.52 & Asthma \\
\hline 6 & $\mathrm{~F}$ & 24 & 29 & Meningitis & 0.92 & Healthy \\
\hline 7 & $\mathrm{M}$ & 24 & 38 & Cellulitis & 0.14 & $\begin{array}{l}\text { C2 deficiency; bacteremia; } \\
\text { recurrent sinusitis; pneumonia }\end{array}$ \\
\hline 8 & $\mathrm{~F}$ & 18 & 23 & Meningitis & 0.19 & Healthy \\
\hline
\end{tabular}

* Patients 1-7 had Hib PS vaccine failure. Patient 7 also had a C2 deficiency. Patient 8 had Hib conjugate vaccine failure. All patients were Caucasian.

$\dagger$ Serum sample obtained 2 to 11 mo after onset of Hib disease (median $=6 \mathrm{mo}$ ). 
Table 2. Results of immunologic evaluation of patients with Hib vaccine failure

\begin{tabular}{|c|c|c|c|c|c|c|c|c|c|c|c|c|}
\hline \multirow[b]{2}{*}{$\begin{array}{c}\text { Subject } \\
\text { no. }\end{array}$} & \multirow[b]{2}{*}{$\begin{array}{l}\text { Age at } \\
\text { study } \\
\text { (mo) }\end{array}$} & \multicolumn{4}{|c|}{ Serum IgG subclasses $(\mu \mathrm{g} / \mathrm{mL})$} & \multicolumn{5}{|c|}{ Peripheral blood lymphocyte population } & \multicolumn{2}{|c|}{$\begin{array}{l}\text { In vitro } \\
\text { secretion (ng/ } \\
\mathrm{mL} / 10^{5} \text { cells) }\end{array}$} \\
\hline & & IgG 1 & $\mathrm{IgG} 2$ & $\mathrm{IgG} 3$ & IgG4 & $\begin{array}{c}\text { Total } \\
\text { lymphocyte } \\
\text { count } / \mathrm{mm}^{3}\end{array}$ & $\begin{array}{l}\mathrm{T} 3 \\
\text { cells } \\
(\%)\end{array}$ & $\begin{array}{l}\mathrm{T} 4 \\
\text { cells } \\
(\%)\end{array}$ & $\begin{array}{l}\text { T8 } \\
\text { cells } \\
(\%) \\
\end{array}$ & $\begin{array}{c}\text { B } \\
\text { cells } \\
(\%)\end{array}$ & $\operatorname{IgG} 1$ & $\operatorname{IgG} 2$ \\
\hline 1 & 48 & 400 & 109 & 54 & 1 & 2688 & 75 & 41 & 21 & 16 & 9530 & 569 \\
\hline 2 & 65 & 572 & 208 & 32 & 27 & 3800 & 80 & 33 & 24 & 9 & 2695 & 204 \\
\hline 3 & 84 & 630 & 120 & 67 & 5 & 3200 & 78 & 42 & 29 & 5 & 2000 & 100 \\
\hline 4 & 71 & 601 & 151 & 60 & 26 & 2806 & 70 & 46 & 27 & 16 & 2136 & 44 \\
\hline 5 & 54 & 376 & 64 & 48 & 17 & 1862 & 80 & 36 & 16 & 5 & $150 \dagger$ & $<10 \dagger$ \\
\hline 6 & 50 & 785 & 64 & 52 & 6 & 7920 & 81 & 42 & 32 & 6 & 760 & 77 \\
\hline 7 & 53 & 501 & 97 & 81 & $<0.4 \dagger$ & 3523 & 58 & 35 & 16 & 37 & 360 & 35 \\
\hline 8 & 30 & 404 & 67 & 28 & 3 & 3864 & 73 & 30 & 17 & 24 & 5156 & 148 \\
\hline
\end{tabular}

* Patients 1-7 had Hib PS vaccine failure. Patient 7 also had a C2 deficiency. Patient 8 had Hib conjugate vaccine failure. All patients were Caucasian.

$\dagger \geq 2$ SD below mean value for age.

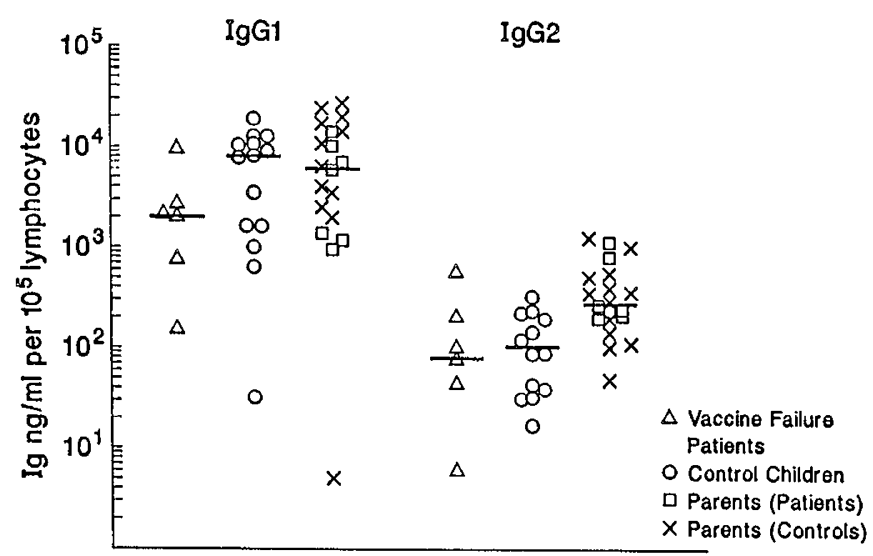

Fig. 1. Secretion of $\operatorname{lgG} 1$ and $\operatorname{lgG} 2$, in vitro, by peripheral blood lymphocytes cultured with a combination of PWM and $S$. aureus Cowan 1. Each point represents the results of studies of cells from an individual subject. The bars represent the respective medians. The data from patient 7 with recurrent infection and $C 2$ deficiency and patient 8 with conjugate failure are excluded (see text). The data for the parents of the contro children and the parents of the patients were not significantly different and, therefore, for calculation of the medians, the data from the two groups were combined. The children with vaccine failure and the control children had lower $\operatorname{IgG} 2$ values than those of the adults $(p<0.05)$. The difference in the $\operatorname{IgG} 1$ secretion between the children with vaccine failure and the control children was not significant $(p>0.2)$. Note that the control child and the control parent with very low $\operatorname{lgGl}$ values are not related and were studied on different days.

of 2067 versus $8085 \mathrm{ng} / \mathrm{mL}$ per $10^{5}$ lymphocytes, $p=0.20$ by Robust analysis). In this analysis, we compared the respective medians in addition to the geometric means because of the outlier value in a control child with a very low IgG1 secretion (Fig. 1). The values for the B-cell secretion of $\mathrm{IgG} 2$ for the children with vaccine failure and the control children were very similar (geometric means of 79 and $89 \mathrm{ng} / \mathrm{mL}$ per $10^{5}$ lymphocytes), but both groups had lower geometric mean IgG2 secretions than that of the B cells of the healthy adults (geometric mean $=302, p<$ 0.05 and 0.01 , respectively). For IgG2, there were no outliers among the controls, and the median values of the three groups $(89,104$, and 277$)$ were very similar to the respective geometric means.

Because of the trend for lower IgG1 secretion by the lymphocytes from the patients, we cocultivated $\mathrm{T}$ - or B-cell fractions from the patients with lymphocytes from their respective parents and measured mitogen-induced secretion of IgG1. The lymphocytes from the healthy parent served as the source of "normal" lymphocytes in this experiment to minimize the allogenic effect that occurs during mixing of lymphocytes from unrelated donors (23). In these experiments, we examined the combination of the patient's B cells and T cells, the patient's B cells and the respective parent's $T$ cells and the patient's $T$ cells and the respective parent's B cells. The results are summarized in Figure 2 and are expressed as the concentrations of $\mathrm{IgGl}$ per $10^{5}$ lymphocytes secreted by the T- and B-cell combination tested. For comparison, we show the geometric mean \pm SD of the IgG1 concentrations in the respective combinations from the healthy control children and their parents.

Lymphocytes from only one of the patients with vaccine failure (patient 5) had subnormal B-cell secretion of IgG1 ( $>2$ SD below the mean for age). $T$ and $B$ cells from two other children with Hib PS failure (patient 6 and patient 7 with $\mathrm{C} 2$ deficiency and recurrent bacteremia) showed values $>1$ SD below the mean for age and $<30 \%$ of the IgG1 secretion of the $\mathrm{B}$ and $\mathrm{T}$ cells of the respective parent measured on the same day (Fig. 2). The corresponding number of healthy control children with IgG1 values $<30 \%$ of that of their respective parent was two of $14(14 \%)$. The results of the different mixing experiments suggested that the low IgG1 secretion of the lymphocytes from patient 5 may have been a result of an intrinsic B-cell defect (i.e. the parent's $B$ cells and the patient's $T$ cells showed normal IgG1 secretion, whereas the patient's B cells with the parent's T cells still had low IgG1 secretion). The results from patient 7 showed a similar pattern. In contrast, the results with the lymphocytes of patient 6 were consistent with possible excessive T suppressor activity. In patient 6 , to distinguish between excessive suppressor activity or a lack of T-cell help, we also examined the effect of the addition of $\mathrm{T}$ cells from this patient on the secretion of $\mathrm{IgG} 1$ by the respective parent's $\mathrm{B}$ and $\mathrm{T}$ cells. The value obtained with the parent's $B$ and T cells was $5900 \mathrm{ng} / \mathrm{mL}$ per $10^{5}$ lymphocytes. Upon the addition of the patient's T cells, secretion of $\operatorname{IgG1}$ decreased to $975 \mathrm{ng} / \mathrm{mL}$ per $10^{5}$ lymphocytes $(84 \%)$.

\section{DISCUSSION}

We investigated secretion of $\operatorname{IgG} 1$ and $\operatorname{IgG} 2$ by mitogenstimulated lymphocytes of children who developed invasive Hib disease despite previous vaccination. The patients were selected based on the presence of low serum anticapsular antibody responses to Hib disease. This latter finding was particularly noteworthy because the children developed disease between 2 to $4 \mathrm{y}$ of age and, therefore, would have been expected to have high anticapsular antibody responses (1). As previously reported (1, 4), their poor anticapsular antibody responses could not be explained by the presence of hypogammaglobulinemia or serum IgG subclass deficiency. 


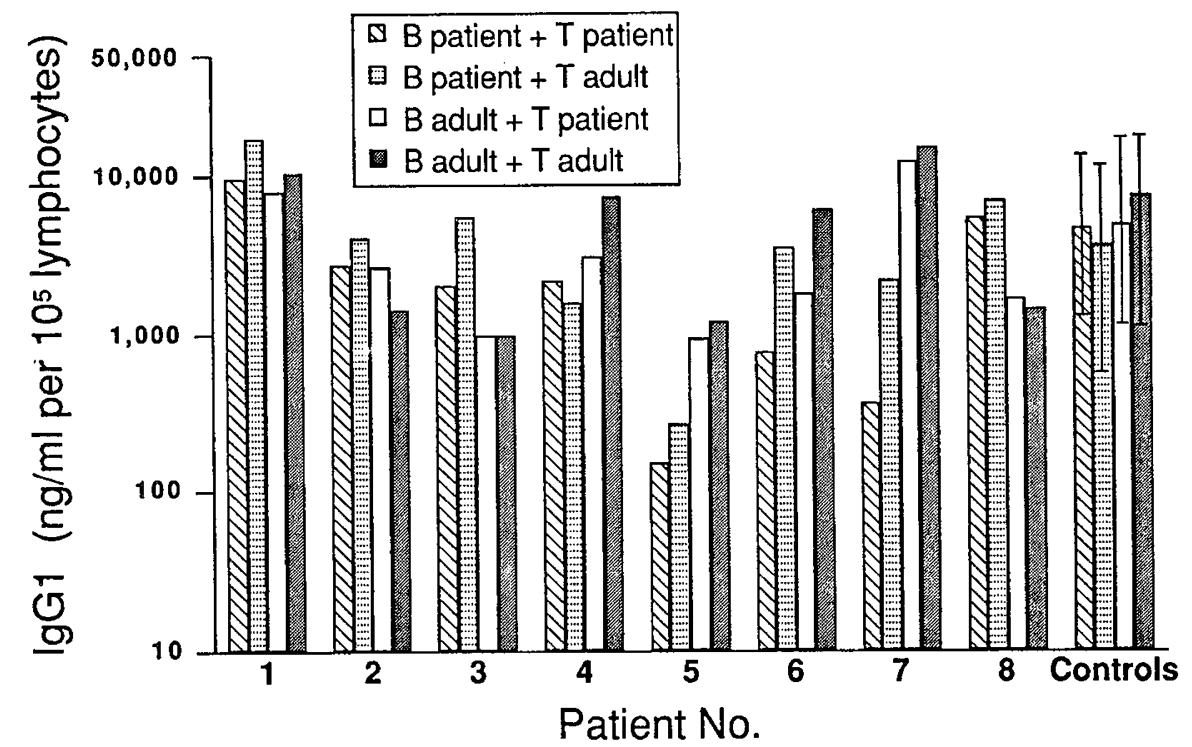

Fig. 2. $\mathrm{T}$ - and B-cell fractions from the patients were cocultivated together or with counterpart lymphocytes from the respective healthy parent in the presence or absence of mitogens (see Materials and Methods). After $7 \mathrm{~d}$ of incubation, $\mathrm{IgG} 1$ was assayed in the supernatants. The results are shown as the concentration of $\operatorname{lgG} 1$ per $10^{\mathrm{s}}$ lymphocytes secreted by the different $\mathrm{T}$ - and B-cell combinations. Respective data from 12 control child-parent pairs are shown as geometric means \pm SD. In this analysis, data from the remaining two control pairs with outlier IgG1 values in a child or a parent were omitted (Fig. 1).

Among the patients, the median B-cell secretion of IgG2 in response to PWM and $S$. aureus Cowan I was nearly identical to that of the B cells of the control children (Fig. 1). However, for IgG1, there was a trend for the children with vaccine failure to have a lower median or geometric mean B-cell secretion than that of the healthy control children (Fig. 1). The difference was not statistically significant $(p>0.2)$, but it is possible that a true difference exists in the average IgGl secretion, and it went undetected because of the small sample size of the patients with this rare condition.

Of the eight patients studied, only patient 5 had subnormal (>2 SD) secretion of IgG1 and IgG2 and, in cocultivation experiments, the lymphocytes from this patient showed evidence of an intrinsic B-cell defect (Fig. 2). As noted above, the serum concentrations of $\operatorname{IgG} 1$ and IgG2 in patient 5 , which reflect Bcell responses to both antigen and mitogen stimulation, were within the normal range (Table 2). In contrast, in the in vitro assay, which measures B-cell responses to mitogens alone, secretion of $\mathrm{IgG1}$ and $\mathrm{IgG} 2$ was abnormal. Shackelford et al. (13) reported that lymphocytes from children with subnormal serum concentrations of IgG2 and impaired antibody responses to Hib PS had subnormal in vitro production of not only IgG2 but also IgG1 and IgG3. These findings were noteworthy because the in vitro data suggested that the immunoregulatory problem in these patients was not limited to IgG2 but involved other IgG subclasses, despite the presence of normal serum concentrations of these subclasses. Thus, despite the presence of normal serum Ig concentrations in patient 5 , the subnormal in vitro secretion of IgG1 and IgG2 by his mitogen-stimulated B cells suggests the possibility of an underlying immune defect associated with the vaccination failure. Note, however, that lymphocytes from healthy individuals also occasionally can show low B-cell secretion of IgG 1 in response to mitogens (Fig. 1). Indeed, lymphocytes from the one adult control with low IgG1 secretion were cultured in vitro on two other occasions over a 4-mo period and were again found to show low IgG1 secretion (unpublished data). Thus, the possible relationship between subnormal B-cell Ig secretion in vitro and the vaccination failure in patient 5 requires additional study.

In humans, PWM is a $\mathrm{T}$ cell-dependent polyclonal B-cell mitogen, whereas $S$. aureus Cowan I is a direct B-cell mitogen. These two mitogens are thought to stimulate different subsets of
B cells $(24,25)$. In the experiments reported here, we used the combination of the two mitogens at two different dose ranges to maximize the Ig secretion compared with when the mitogens are used separately (24). Because different cell populations are thought to be stimulated by the different mitogens, it is possible that a significant difference in $\mathrm{IgG} 1$ or IgG2 secretion between our patients and controls might have been detected if the mitogens had been used separately. However, in other experiments, when lymphocytes were stimulated with PWM alone, we found no significant difference between patients with vaccine failure and control children in the respective IgG1 or IgG2 secretion (unpublished data). To date, the responses to $S$. aureus Cowan I alone have not been examined.

In our in vitro studies, we did not attempt to measure antigenspecific responses. Previous efforts to measure plaque-forming cells or specific antibody secreted by B cells stimulated in vitro with PS antigens demonstrated minimal (26) or no triggering of specific antibody formation or proliferative responses (27). When tested in vitro, Hib PS is reported to be a poor mitogen (28). Although it is possible to measure in vitro antibody secretion of B cells from individuals vaccinated in vivo with PS $(26,28-30)$, such $B$ cells remain in the peripheral blood only transiently after vaccination, and, when the cells are cultured in vitro, the responses appear to be minimally affected by exposure to antigens $(26,27)$.

The biologic basis for the impaired serum anticapsular antibody responses of patients with Hib PS vaccine failure remains poorly understood. Most patients have normal serum concentrations of $\operatorname{Ig}(1,4)$. The present results also suggest that most patients have normal in vitro B-cell secretion of IgG1 and IgG2 in response to mitogens, although, as noted above, we cannot exclude the possibility that the average IgG1 secretion in the patients is lower than that of the controls (Fig. 1). In previous studies, the most notable findings in patients with Hib PS vaccination failure were impaired serum antibody responses to Hib PS $(1,4)$, despite normal serum concentrations of $\operatorname{Ig}(1,4)$ and normal antibody responses to tetanus toxoid (1) and pneumococcal type 3 PS (Granoff DM, unpublished data). Furthermore, as noted earlier, the antibody unresponsiveness to Hib PS can be overcome by vaccination with Hib PS-protein conjugate vaccines $(5,6)$. Taken together, these data suggest that the impaired serum antibody responses to Hib PS are a result of either an exaggerated 
physiologic delay in the normal age-related development of antibody response to this antigen or, possibly, to transient tolerance induced by vaccination with Hib PS. In both instances, the antibody unresponsiveness would be expected to be antigen specific, transient, and potentially capable of being overcome by vaccination with an Hib PS-protein conjugate. The conjugate vaccination is thought to provide additional signals to the $B$ cells that are unresponsive because of either a maturational delay, or because they have been rendered unresponsive by exposure to the unconjugated PS. However, it remains possible that some of the children may have an evolving immunodeficiency. Therefore, it will be important to continue to follow their clinical courses and serum Ig concentrations to determine whether additional immunologic dysfunction develops.

\section{REFERENCES}

1. Granoff DM, Shackelford PG, Suarez BK, Nahm MH, Cates KL, Murphy TV, Karasic R, Osterholm MT, Pandey JP, Daum RS 1986 Haemophilus influenzae type b disease in children previously vaccinated with type b polysaccharide vaccine. N Engl J Med 315:1584-1590

2. Hines EE, Frasch CE 1988 Spectrum of disease due to Haemophilus type b occurring in vaccinated children. J Infect Dis 158:343-348

3. Osterholm MT, Rambeck JH, White KE, Jacobs JL, Pierson LM, Neaton JD, Hedberg CW, MacDonald KL, Granoff DM 1988 Lack of protective efficacy associated with Haemophilus influenzae type b polysaccharide vaccination in Minnesota children. JAMA 260:1423-1428

4. Granoff DM, Sheetz K, Pandey JP Nahm MH, Rambeck JH, Jacobs JL, Musser J, Selander RK, Murphy TV, Osterholm MT 1989 Host and bacterial factors associated with Haemophilus influenzae type b disease in Minnesota children vaccinated with type b polysaccharide vaccine. J Infect Dis 159:908916

5. GranoffDM, Chacko A, Lottenbach KR, Sheetz KE 1989 Immunogenicity of Haemophilus influenzae type b-polysaccharide outer membrane protein conjugate vaccine in patients who acquired Haemophilus disease despite previous vaccination with type b polysaccharide vaccine. J Pediatr 114:925933

6. Weinberg GA, Murphy TV, Granoff DM 1990 Haemophilus influenzae type $b$ polysaccharide-diphtheria toxoid conjugate vaccine in vaccinated children who developed Haemophilus disease. Pediatrics 86:617-620

7. Lucas AH, Granoff DM 1990 A major crossreactive idiotype associated with human antibodies to the Haemophilus influenzae b polysaccharide. J Clin Invest 85:1158-1166

8. Schneerson R, Barrera O, Sutton A, Robbins JB 1980 Preparation, characterization and immunogenicity of Haemophilus influenzae type $b$ polysaccharide-protein conjugates. J Exp Med 152:361-376

9. De la Concha EG, Oldham G, Webster ADB, Asherson GL, Platts-Mills TAE 1977 Quantitative measurements of T- and B-cell functions in "variable" primary hypogammaglobulinemia: evidence for a consistent B-cell defect. Clin Exp Immunol 27:208-215

10. Pawha SG, Hoffman MK, Pawha RN, Good RA 1982 Polyclonal and antigenspecific B-cell responses in patients with common variable immunodeficiency. J Clin Immunol 2:205-213

11. Geha RS, Schneeberger E, Gatien J, Rosen FS, Merler E 1974 Synthesis of an
M component by circulating B lymphocytes in severe combined immunodeficiencies. N Engl J Med 290:726-728

12. Quinti I, Geha RS, Papetti C 1986 Lymphocyte abnormalities in patients with IgG subclass deficiency. In: Aiuto F, Rosen F, Cooper MD (eds) Recen Advances in Primary and Acquired Immunodeficiencies. Raven Press, New York, pp 165-173

13. Shackelford PG, Granoff DM, Polmar SH, Scott MG, Goskowicz MC Madassery JV, Nahm MH 1990 Subnormal serum concentrations of IgG2 in children with frequent infections associated with varied patterns of im munologic dysfunction. J Pediatr 116:529-538

14. Shackelford PG Granoff DM, Madassery JV, Scott MG, Nahm MH 1990 Clinical and immunologic characteristics of healthy children with subnorma serum concentrations of IgG2. Pediatr Res 27:16-21

15. Saxon A, Kobayashi RH, Stevens RH, Singer AD, Stiehm ER, Siegel SC 1980 In vitro analysis of humoral immunity in antibody deficiency with normal immunoglobulins. Clin Immunol Immunopathol 17:235-244

16. Knutsen AP, O'Connor DM 1985 Antibody deficiency with normal immunoglobulins in a child with hypoplastic anemia. Clin Immunol Immunopathol 36:330-337

17. Madassery JV, Kwon OH, Lee SY, Nahm MH 1988 IgG2 concentration among 8015 blood donors. Clin Chem 34:1407-1413

18. Boyum A 1968 Isolation of mononuclear cells and granulocytes from human blood: isolation of mononuclear cells by one centrifugation and of granulocytes by combining centrifugation and sedimentation at $\mathrm{lg}$. Scan J Clin Lab Invest (suppl 21):77

19. Butch AW, Macke KA, Scott MG, Inkster M, Nahm MH 1989 Mitogeninduced human IgG subclass expression II. IgG1 and IgG3 subclasses are preferentially stimulated by a combination of Staphylococcal aureus Cowan I and pokeweed mitogen. Hum Immunol 24:207-218

20. Scott MG, Nahm MH 1984 Mitogen-induced human IgG subclass expression. J Immunol 135:2454-2460

21. Jefferis R, Reimer CB, Skvaril F, deLong G 1985 Evaluation of monoclonal antibodies having specificity for human IgG subclasses: results of an IUIS/ WHO collaborative study. Immunol Lett 10:223-252

22. Reimer CB, Phillips DJ, Aloisio H, Moore DD, Gallard GG, Wells TW, Black CM, McDougal JS 1984 Evaluation of thirty-one mouse monoclonal antibodies to human IgG epitopes. Hybridoma 3:263-274

23. Corley RB, Kindred B, Lesckovits I 1978 Positive and negative allogenic effects mediated by MLR primed lymphocytes: quantitation by limiting dilution analysis. J Immunol 121:1082-1089

24. Saike O, Ralph P 1981 Induction of human immunoglobulin secretion. I. Synergistic effect of B-cell mitogen Cowan I plus T cell mitogen or factors. J Immunol 127:1044-1047

25. Kansas GS, Wood GS, Englemen EG 1985 Maturational and functional diversity of human B lymphocytes delineated with anti-Leu-8. J Immunol 134:3003-3006

26. Rijker GT, Mosier DE 1985 Pneumococcal polysaccharides induce antibody formation by human B lymphocytes in vitro. J Immunol 138:1-4

27. Kehrl JH, Fauci AS 1983 Activation of human B lymphocytes after immunization with pneumococcal polysaccharides. J Clin Invest 71:1032-1040

28. Sik Shin H, Stein KS 1990 Mitogenic responses to H. influenzae polysaccharides. [letter] J Immunol 145:2772-2773

29. Ambrosino DM, Delaney NR, Shamberger RC 1990 Human polysaccharidespecific $B$ cells are responsive to pokeweed mitogen and IL-6. J Immunol 144:1221-1226

30. Munoz JL, Insel RA 1987 In vitro human antibody production to the Haemophilus influenzae type b capsular polysaccharide. J Immunol 139:20262031 